\title{
Rachel (Rae) Dalven: An Accomplished Female Romaniote Historian, Translator, and Playwright
}

\begin{abstract}
Rachel Dalven was a Romaniote Jew, translator of modern Greek poetry, playwright, and historian of the Jews of Ioannina, Greece. She was an educated and well-traveled independent woman, who brought to the Englishspeaking audiences in the West the poets Cavafy, Ritsos, and Yosef Eliya as well as many female Greek poets. She visited the Jewish community of Ioannina several times in the 1930s, and wrote about the deportation and annihilation of the Jews from Ioannina in Auschwitz-Birkenau. She was a cross between a Greek-speaking Romaniote Jew and a Sephardic Jew, both little-known subgroups within the Jewish minority. Residing in New York City, she benefited from being in a rich cultural hub with its connections and benefits in encouraging and enabling translation, poetry, theater, academic research, publishing, and travel grants.
\end{abstract}

Keywords: Rachel Dalven, Yosef Eliya, Cavafy, Ritsos, Ioannina, Romaniote, Judeo-Greek, Holocaust.

Rachel Dalven, born in Preveza, Greece, on 25 April 1904, came from a Judeo-Greek speaking, Jewish Romaniote family from Ioannina, Greece, that migrated to the United States in 1910 when she was five. She grew up in the area of New York and was a part of the Jewish Ioanniote Greekspeaking community that was active in four neighborhoods: the Lower East Side of Manhattan, Harlem, Brooklyn, and the Bronx. She had many relatives in New York and Ioannina. She would become a pioneer in researching the history and culture of the Romaniote Jewish community of Ioannina as well as a translator of Greek poetry into English, 
a playwright, and a professor of English literature and the department chairperson at Ladycliff College in Highland Falls, New York. She did her studies at Hunter College and received a doctorate in English from New York University. Toward the end of her life, she taught modern Greek literature at the Onassis Program in Hellenic Studies at New York University. She died in New York City on 30 July 1992.

\section{Rachel Dalven as a Translator of Poetry from Greek to English}

Rachel Dalven was an active and noted translator of modern Greek poetry into English. The descriptions below attempt to trace the vast numbers of her translations, which poets she translated, and, when possible, the past critiques of her works. Time and space limit a linguistic analysis of her translations so that we might also note her creations as a playwright and her monumental activities in annotating the history of the Jews of Ioannina, and their Romaniote culture. As a Jewish female twentieth-century scholar of Romaniote Jews in the Greek Peninsula and a translator, she is second to none as a Jewish female cultural icon of the southern part of the Balkans.

Cavafy's famous poem "Ithaka," first published in 1911, was only five stanzas long, but it is one of his most known poems and is considered to express his outlook on life. The poem is colloquial in its language. The narrator, probably well-traveled, addresses either Odysseus, the hero of Homer's epic Odyssey, or an imaginary modern traveler or reader. The first English translation appeared in 1924, but due to the difficulties in translating Cavafy, very few pursued tackling his unorthodox style, and Dalven's translations, made decades later in the late 1950s, eventually brought the Greek-speaking Alexandrian Cavafy (d. 1933) posthumously to international notoriety outside the Greek-speaking centers of Greece and Cyprus-and for this she became known for her translations by scholars, literary critics, and publishers and editors of modern Greek poetry and poetry in general. The criticism of Dalven's translation in a critical edition for students was as follows:

Jane Lagoudis Pinchin, in Alexandria Still, evaluates the different translations of the poem, including the first published translation by George Valassopoulo, and the translations by Rae Dalven and John Mavrogordato. Pinchin prefers Mavrogordato's version of the last line of the poem ("You will have understood the meaning of an Ithaka") to Dalven's version ("You must surely have under- 
stood by then what Ithacas mean"). Pinchin comments, "Dalven does sound a bit impatient with her dim voyager."1

After Dalven published her first translations of modern Greek poetry in the book Modern Greek Poetry (Gaer, 1949), it was reviewed by W. H. Auden, who wrote, "We should be very grateful to Miss Dalven for introducing us to the world of poetry which has been closed to us" by the language barrier. Afterward he wrote the introductions to Dalven's The Complete Poems of Cavafy and The Fourth Dimension, discussed below.

In 1961 Dalven published a collection of poems by the little-known Alexandrian poet C. P. (Konstantinos Petros) Cavafy entitled The Complete Poems of Cavafy, which popularized Cavafy among the broader Englishspeaking public. ${ }^{2}$ While Oxford scholar John Mavrokordatos completed his collection of translations of Cavafy in 1937, four years after the death of the poet, it was only published in 1951 and included the canon of 154 poems known at the time. Dalven published the same canon as well as an additional several dozen poems. Her translation was recommended for publication and contained a preface by W. H. Auden. She was criticized by D. J. Enright as a translator for using a misleading title since she did not translate all the known poems, and for being "less mannered in style than Mavrokordatos" and "lacking a clear guiding principle" in her translation, but she did popularize Cavafy, ${ }^{3}$ and her translation was in the literary focus until modern Greek scholars Edmund Keeley and Philip Sherrard published a new scholarly translation in $1975 .{ }^{4}$

Dalven's second note of notoriety was achieved as a result of her translation of The Fourth Dimension: Selected Poems of Yannis Ritsos (David R. Godine, 1977). ${ }^{5}$ The Greek poet Yannis Ritsos was a communist who fought in the underground in World War II and was sentenced to forced labor as a political prisoner first on the island of Limnos and then at the infamous camp on Makronisos for a combined total of four years during the Civil War (1944-1951). ${ }^{6}$ His poems were banned until 1954 and again

1 "Ithaka," Poetry for Students 19 (2004), 111-128.

2 Rae Dalven, The Complete Poems of Cavafy (New York-London, 1961).

${ }^{3}$ Sarah Ekdawi, “C. P. Cavafy 1863-1933, Greek Poet," in Encyclopedia of Literary English into English (London, 2002), 240-241.

${ }^{4}$ Constantine P. Cavafy, Collected Poems, trans. Edmund Keeley, Philip Sherrard (Princeton, 1975).

5 The Fourth Dimension: Selected Poems of Yannis Ritsos, trans. and introd. Rae Dalven (Boston, 1977).

6 “A Note on Yannis Ritsos," Poetry 103 (1964), 5:334. 
during the Greek Junta dictatorship (1967-1974). Dalven's translations were amongst the first after the dictatorship ended.

Dalven also translated the poems of the young prolific Jewish Greek poet Yosef Eliya ${ }^{7}$ of Ioannina, a national Greek literary icon, who died in early 1931 aged only twenty-nine, after drinking polluted water. Her translations were published in 1944 by Anatolia Press in New York. Theodora Patrona coined her a "cultural ambassador" between the two countries, the United States and Greece, for this translation and for being the first translator of the complete poems of Cavafy into English. ${ }^{8}$ Dalven's translations of Eliya were some of the earliest translations of Greek poetry published at a very early stage of English translations of Greek poetry in the United States and elsewhere outside Greece. ${ }^{9}$

7 Joseph Eliya, Poems, trans. Rae Dalven (New York, 1944).

8 Theodora D. Patrona, "The Forgotten Female Voices of the Greek Diaspora in the United States," The Journal of Modern Hellenism 31 (2015), 87-100.

${ }^{9}$ Eliya taught French at the Alliance Israélite Universelle school in Ioannina, his native town, and then for a year in Kilkis, Macedonia (Greece), before his tragic death in 1931. Dan Cohn-Sherbok noted in The Blackwell Dictionary of Judaica that Eliya wrote poetic love songs dedicated to Rebekah and also produced Greek translations of Isaiah, Job, the Song of Songs, Ruth, and Jonah, as well as the works of medieval and modern Jewish writers; see Dan Cohn-Sherbok (ed.), The Blackwell Dictionary of Judaica (Oxford, 1992). A street was named after Eliya in the new Jewish quarter of Ioannina outside the walls of the Old City. There is also a bust of Eliya in Alsos Park in Ioannina. Bracha Rivlin in the introduction to Pinkas ha-kehilot Yavan, published by Yad Vashem, wrote, "The greatest Jewish poet writing in Greek, Yosef Eliya of Ioannina, translated poems of Rabbi Yehuda Halevi, Ibn Gabirol, as well as Bialik and Tchernichovsky from Hebrew into Greek;" see Bracha Rivlin, Yitzchak Kerem, Lea Matkovetski, Pinkas ha-kehilot Yavan (Jerusalem, 1999), 26. Giorgios Zografaki wrote a Greek anthology of his poetry entitled Song of Songs - Psalms that was published in Greek; see Giorgios Zografaki, Song of Songs - Psalms (Athens, 1981). Leon Narr amassed and edited an updated compendium of the entire known works of Yosef Eliya in a two-volume work published in Athens in 2009. In the second volume, Narr made comments illustrating the main identity issues which Greece encountered in the interwar period, such as Eliya's quest for social justice, his search for the essence of "Greekness," and the need to recreate a new Greek Jewish identity, especially in light of the transition from 450 years of Ottoman rule and traditional life to a new identity under the Greek Republic; see Leon A. Narr (ed. and introd.), Gioséf Eligiá Apanta, vol. 2 (Athens, 2009). Yitzchak Kerem wrote on Eliya in the New Encyclopedia Judaica; see Yitzchak Kerem, "The Jew in Modern Greek Literature," New Encyclopedia Judaica (Jerusalem, 2007-2008), 8:63-65. In commemoration of the seventieth anniversary of the deportation of the Jews of Ioannina to Auschwitz, a concert of Greek Jewish music based on the poems by Eliya, written and performed by Pighi Likoudi and her musicians, was held at the Centre Communautaire Laïque Juif David Susskind in Bruxelles, Belgium, in March 2014. See Efthymios Tsiliopoulos, "Ioannina Jews Remembered," New Greek News about Greece \& Greeks Around the World (17 March 2014), http://www.newgreektv.com/english-news/ item/4431-ioannina-jews-remembered [retrieved: 28 Aug. 2017]. At the Jewish Museum in Athens two temporary exhibitions on Ioannina's Jews were organized from 23 January to 25 September 2017. The exhibition "Joseph Eliya: Poet of the Lake" was dedicated to 
Research by Eleni Kourmantzi notes that in addition to Eliya's lyrical poetry, his main work contains numerous examples of protest poetry against conservative political ideology which oppressed workers, communists and socialists, social outcasts, prostitutes, and others. She states that in his poems "Torah" and "The Pharisee," he protested against leaders of the Jewish community of Ioannina. A product of an Alliance Israélite Universelle modern Jewish education in Ioannina, he had protested the school's contempt for Zionist ideology, but also benefited from his modern French education by being exposed to the ideals of the French revolution. Inspired by the quest for liberty and equality, he sympathized with workers and sought to create a socialist egalitarian society. In Salonika (Thessaloniki) ${ }^{10}$ numerous Alliance graduates were part of the socialist Salonikan Labor Federation and active members of the Socialist International. Eliya was

the life and work of the eminent philosopher and poet. See "What's On, 'Ioannina's Jews. Athens, 23 January - 25 September'," Kathimerini (21 Jan. 2017), http://www.ekathimerini.com/215487/article/ekathimerini/whats-on/ioanninas-jews--athens--january-23--september-25 [retrieved: 26 Sept. 2017]. Noteworthy are also recent analyzes of Eliya within modern Greek literature and poetry, his radical ideological positions, and the novelty of his work in integrating classical biblical scholarship, Hebrew philology, and Jewish thought and philosophy into modern Greek culture. He often used the pseudonym Ioulios Singulieros, writing critical poems against militarism, expressing syndicalist proletarian concerns, and protesting the fascist behavior of the governmental authorities against workers. He wrote poetry in demotic Greek so that a typical Greek-Orthodox person could understand his translations from the Old Testament, and for the benefit of most of the Jews of Ioannina who did not understand Hebrew. He translated medieval Hebrew poets, e.g. Yehuda Halevi and Ibn Gabirol, into Greek as well as modern Hebrew writers, such as Bialik, Tchernichovsky, Frishman, Peretz, and Shneur. In his poetry he voiced concern for syndicalism and the risk of evolving fascism during this time period. He also thought the Jewish community of Ioannina could not contend with the hostile extremism of the ultra-nationalist EEE (the National Union of Greece), and the Asia Minor refugees against the Jews. He added the study of Jesus to his literary activities in order to understand Christian society, but also boldly condemned Christian persecution of Jews; both phenomena being discussed publicly, embarrassed the conservative apologetic establishment of the Jewish community of Ioannina. In another controversial poem, entitled "Militarism and the Pharisees," he warned against those persecuting erudite theological and intellectual thinkers, and his remarks were aimed against the Jewish community leadership for fearing and repressing critical thought. After his death at the young age of twenty-nine, he was eulogized as a radical author. He also was lauded as a pioneer in setting the course as a conscious proletarian intellectual. See Panayiotis Noutsos, "Ta Giánnina, o Eligiá kai to dípolo 'fasismós' kai ‘antifasismós' toy mesopolémoy,” Chroniká 126 (1993), 21-27.

${ }_{10}$ The article will use the Jewish Ottoman terms and spellings, used by Jews, to call cities currently in Greece like Salonika instead of Thessaloniki, and Castoria instead of Kastoria. Since the Jews spoke Greek in Ioannina, the latter Greek spelling for the city will be used. In the United States the Jews from Ioannina used a more Americanized adaptation for the city, "Janina," but the latter name will only be used in the article to describe names of their synagogues. 
feared by the authorities in Ioannina as a dangerous radical, and they influenced the local Jewish community there to release him from his teaching position at the Alliance Israélite Universelle school; he was forced to go into exile from his town Ioannina, and took a teaching position in a high school in a remote small Macedonian town, Kilkis, north-east of Salonika. In his last poem, written while he was teaching in Kilkis, entitled "Moses the Seducer," the reader can see the natural synthesis that Eliya found between Judaism and Hellenism. He wrote of "Moses the innocent and pure seducer with a beautiful exhilaration of yearning and ideas, with Greece with a mellifluent voice and with a flaming spirit of a Jew." 11

Dalven wrote the following about Eliya as a translator and poet, and his message for religious tolerance:

Eliya began translating the Old Testament into demotic Greek, officially in disrepute, hoping thereby both to acquaint the Romaniote community (many of whom did not know Hebrew) with their own Hebrew heritage and make the Old Testament available to his Christian compatriots in the language they could understand. He also published poems in local newspapers under the pseudonym Ioulios Singulieros. All of his poems exhibit a broad religious tolerance. The main burden of his struggle was to enlighten the timid, appeasing Jewish leaders so his coreligionists would never again be persecuted. He sought to open their eyes to the existence of other faiths, to accept them and have friendly relations with them, which, at the time he was writing, they could not or would not do. ${ }^{12}$

Dalven never intended to be a translator, but once on a trip to Paris, she met a cousin, Marcos, who told her about their talented relative Yosef Eliya, a struggling young Greek poet, a scholar of Hebrew studies, and a translator of the Old Testament and biblical Hebrew into demotic Greek. ${ }^{13}$ She immediately sent him 50 dollars for financial assistance, and was in correspondence with him for three years until his untimely death in Greece. In 1935 Dalven and her husband went to Ioannina for Marcos's wedding, and Eliya's mother, Hanoula, requested or demanded that Dalven translate Eliya's poems into English as part of the latter's dying wish. She began to

${ }^{11}$ See Eleni Kourmantzi, "Gioséf Eligiá: Dianooýmenos kai poietés tes 'diamartyrías'," in Anna Mahera, Leda Papastefanaki (eds.), Evraïkés koinótetes anámesa se Anatolé kai Dýse, 15os-20ós aiónas: oikonomía, koinonía, politiké, politismós (Ioannina, 2016), 106-114. On Eliya see also: Dimitris Kargiotis, "Asma Asmáton: E ypógeia parémvase toy Gioséf Eligiá sto neoellenikó logotechnikó kanóna," in Mahera, Papastefanaki (eds.), Evraïkés koinótetes, 115-126.

12 Rae Dalven, The Jews of Ioannina (Philadelphia, 1990), 168.

${ }^{13}$ Rae Dalven, "An Unsought for Calling (My Life as a Translator from the Modern Greek)," Journal of Modern Greek Studies 8 (1990), 2:307-315. 
translate the poems after her teaching hours in New York, and returned to Ioannina on her own during the summers of 1936 and 1937. She met Eliya's literary colleagues in Ioannina and Athens as well as the editors of Nea Estia and the Large Greek Encyclopedia where Eliya had published articles on Jewish life in Greece. On these trips she also saw the Jewish community of Ioannina before the deportation and annihilation of its members in Auschwitz-Birkenau in early April 1944. Her notes and impressions would become a part of future articles and her book on the Jews of Ioannina.

By 1938, Dalven finished her translation of ninety of Eliya's poems (out of his total of 250) and wrote a short biography. She had problems finding a publisher, was unsuccessful in getting commitments from 1,000 Ioanniote Jews to buy the book, and resolved to publish the translations weekly over the next two years in the English section of the Greek National Herald, but in the end received financial support from a cousin of Eliya in Manhattan. ${ }^{14}$ Around 1944/45, the book finally appeared under the title Poems. After the collection was printed and Dalven began selling copies, Vladmir Constantinides, the editor of the Greek American newspaper Atlantis, was ecstatic about the edition and Dalven's translations. He reviewed Poems in his editorial column in three different Sunday issues, and this exposure snowballed. Dalven was invited to organizations and churches to promote the book. With its publication, Dalven attained a reputation as a recognized translator from modern Greek, a novel idea at the time.

In 1947 in Paris Dalven met the renowned Greek author Nikos Kazantzakis, and he offered her the opportunity to translate into English and publish in the United States his huge Greek edition of The Odyssey published in Athens. She translated twenty pages while in Paris, and was intent on continuing in New York, but friends convinced her that the project would take years and that she was taking on too much. She abandoned the idea, but included the twenty pages in her volume Modern Greek Poetry, published in $1949 .{ }^{15}$

Dalven's final published translation was Daughters of Sappho ${ }^{16}$ which appeared after her death in 1994. This book is an anthology of translations from Greek representing twenty-five contemporary women poets, encompassing authors writing between the 1920s and the early 1990s. Each poet is

14 Ibid., 308-310.

15 Rae Dalven, Modern Greek Poetry (New York, 1949).

${ }^{16}$ Rae Dalven (ed. and trans.), Daughters of Sappho: Contemporary Greek Women Poets (Rutherford, 1994). 
introduced in a short biography: Maria Polydhouri, Zoe Karelli, Rita Boumi Pappa, Dhialehti Zevgholi Ghlezou, Alexandra Plakotari, Melissanthi, Ioanna Tsatsou, Heleni Vakalo, Lina Kasdhaghli, Olga Votsi, Victoria Theodorou, Lydia Stephanou, Maria Servaki, Maria Kentrou-Agathopoulou, Kiki Dhimoula, Nana Issaia, Yolanda Penghli, Zephy Dharaki, Katerina Anghelaki-Rooke, Pitsa Ghalazi, Ioanna Servou, Rea Ghalanaki, Pavlina Pampoudhi, Jenny Mastoraki, and Veronica Dhalakoura.

This anthology of close to two hundred poems was unique in that it was the first comprehensive collection in English to reveal contemporary Greek women's poetry in Greece. In the first decades of the twentieth century female poets in Greece faced discrimination by the patriarchal society. Maria Polydhouri (1902-1930) was the first contemporary Greek female poet to achieve prominence beyond the country's borders. She wrote romantic and erotic poetry since love was the only acceptable theme for women to pursue. However, in the 1930s, in a period of political chaos that saw the change from the Venizelos republic to the Metaxas dictatorship, women poets emerged in an attempt to fight the intellectual deterioration and poetic sterility of the era. In order to achieve their identity in the hegemonic male society, they lauded Sappho for her language, free expression of emotions, and devotion to the quest for individual freedom for women. In the 1930s, Greek female poets composed poetry in free verse and in demotic Greek. They also were inspired by Europe for poetic inspiration and growth. The poetry of the 1930s was diverse and non-conformist poetically, borrowing from both the East and West in nature and motifs. Karen Van Dyck, an authority on the translation of modern Greek poetry, wrote in the preface: "In this anthology we are very fortunate to have a space for these alternative visions of nationhood, gender, and genre. It is through such cross-cultural endeavors that we can avoid generalization and emphasize instead the specificity of cultural production." ${ }^{17}$ In the introduction to the book it was noted that since the early 1930s, when Greek women began to free themselves from the male authority of fathers, brothers, and husbands, and were no longer solely homebound and isolated from public, economic, and social life, "the main focus of women's poets, in their long struggle for equality with men, has been to be able to function freely in terms of their own consciousness and their existence in a man's world." 18

${ }^{17}$ Karen Van Dyck, "Preface," in Dalven (ed. and trans.), Daughters of Sappho, 1.

18 Dalven (ed. and trans.), Daughters of Sappho, 20. 
By the 1960s and 1970s, especially during the Junta dictatorship, Greek female poets used their lyrical voices as part of the resistance, and often were "daringly defiant." ${ }^{19}$ In her book, Dalven also included the Jewish woman poet of Romaniote origin Nana Issaia (b. 1934), who was a painter and a seminal poet of the 1960s. In her first volume Poems, published in 1969, she was influenced by the confessional poetry of Sylvia Plath, and the work "represented the nihilistic mode of the existential imagination, which perceived nothingness as a terrifying realm with absolute self-destructive limits." ${ }^{20}$ In 1974 Issaia translated Plath's poetry into Greek. According to Issaia, her poetry was based on a descent to level zero, which in her view was the symbol of a dialectical political state. Influenced by Martin Heidegger, she "believed that in the nothingness of a zero state, the essence of our being can be discerned. It was this essence, using an austere form, that she was trying to express. Because the unreal, and yet very real, does need a great precision of expression, rhythm, and synthesis." ${ }^{21}$ Issaia did not recognize daily life. For her, death was the pinnacle of dreams and small thoughts, which in her view were the basic assumptions of every art.

Significant for Greek society was the inclusion of Ioanna Tsatsou (1909-2000), who wrote on the German occupation and was the sister of the Nobel Prize-winning Greek poet George Seferis, and the wife of Constantine Tsatsos, an academic and a former President of Greece. In 1965 Ioanna Tsatsou published works about her experiences in the resistance- as an aide and under the patronage of Archbishop Damaskinos who protested the deportation of Salonikan Jewry to Auschwitz-in a book entitled The Sword's Fierce Edge: A Journal of the Occupation of Greece, 1941-1944. Her first book of poetry, Words of Silence, published in 1968, was universally acclaimed and was followed by fourteen volumes of poetry; they were all bound in one book called Poems, published in 1986. Her poetry is very lyrical and profoundly religious and metaphysical. She also dwelled on the inevitable-death. ${ }^{22}$

Dalven included female poetic voices who also endured the painful Civil War, stimulated national conscience, protested oppression, and fought for women's rights. Victoria Theodorou (b. 1926) wrote Women's Concentration Camps, a chronicle of the Civil War in Greece, first published in 1975

\footnotetext{
19 Ibid., 26.

20 Ibid., 162.

21 Ibid., 163.

22 Ibid., 91-98.
} 
after the dictatorship. She was one of the incarcerated and the book was based on nine buried notebooks recollecting the narrations of women in the concentration camps of Chios, Trekeri, and Makronisos from 1947 to 1952. As a poet, she emulated Sappho in the political struggles of her contemporary world. From 1941 to 1945 she served as a messenger in the Greek resistance. In her poems one sees the progression of her experiences: resistance, exile, and post-trauma; rage, memory, and feelings. Dalven included the poems "How Was I Trapped," "Life Sentences," "When," "I Seek Harmony," "Bring Back Feeling," and "I Will Remain Here with My Rage." ${ }^{23}$ In the last poem, the poet did not seek revenge, but felt blessed by being given fruit to live, and wanted to play the lute again. She noted how the collaborator endured like a vine, but she hoped that that hubris, menace, and decomposition would be expunged.

Two translations of Dalven still remain unpublished: To Become "Great" by Elly Alexiou and The Ancestor, a play by Angelos Terzakis, which was produced in 1970. Born in Nauplion in the Peloponnese, the southern peninsula of Greece, Terzakis was an author and a playwright of the 1930s, the generation of the depression and of the transition between The Democratic People's Republic of Greece and the Metaxas dictatorship.

In the greater historical perspective Dalven has been noted as a pioneer for bringing translations of modern Greek poetry to the United States, and hence to popularity in the Greek diaspora and globally. Orestes Varvitsiotes, in a review of Modern Greek Poetry in Translation by Nanos Valaoritis and Thanasis Maskaleris, wrote:

This may sound like a paradox today. But that's how the situation was then, before American and English academics established the significance of modern Greece in poetry; before Ritsos and Kazantzakis became known and appreciated. Even Cavafy was hardly known then. In this connection, it must be mentioned here that two American academics played a pioneering role in the discovery in this country of Modern Greek poetry: Kimon Friar, by his translation of Kazantzakis' Odyssey: A Modern Sequel, and Rae Dalven's first translation of the poetry of Cavafy and Ritsos. In fact, it was in the introduction to her book that the English poet, W. H. Auden, underscored the great significance of Cavafy's work in the literature of the Twentieth Century and his influence on the work of other poets. ${ }^{24}$

23 Ibid., 117-122.

${ }^{24}$ Orestes Varvitsiotes, "Book Review: Modern Greek Poetry in Translation," Greek News (5 June 2005), http://www.greeknewsonline.com/book-review-modern-greek-poetryin-translation/ [retrieved: 30 Sept. 2017]. 
Dalven was often lauded for her translations, for exposing unknown Greek poets to the West, and was sometimes critiqued for not having enough sophistication in translating or finding parallels between modern Greek and English. Cavafy was difficult to translate since he had an unorthodox sense of expression, introduced local colloquialisms, and often was overly tangential. His clichés and metaphoric phrases were difficult to translate and were often convoluted, deeply emotional, and sometimes even bordered on trite. Neither Dalven, Sheppard, and Keeley nor others could fully translate Cavafy's diasporic Greek means of expression, but they captured his grandeur and novelty. The London Review of Books critic Charles Simic noted that as great a poet as Cavafy was, his poetry, full of clichés, provided a hopeless challenge for translators. ${ }^{25}$

A scholar specializing in the translation of modern Greek poetry, Karen Van Dyck of Columbia University, wrote that "Like flags and foustanellas, and other more patriotic fetishes, Greek poetry inscribes notions of national, linguistic, and generic piety. It is the measure of what is most Greek." ${ }^{26}$ She noted that Greek poetry haunted Greek Americans as well as Greek cultural production. This provided the drive for Dalven to propagate Greek culture and poetry as well as depict the experience of the Greek Jewish immigrant to the United States and the history and the culture of the Jews of Ioannina, back in their community of origin in the Ottoman Empire and in the modern Greek state. Dalven was proud of her Greek and Jewish heritages and blended both of them in her literary and scholarly activities. Van Dyck gave credit to Dalven for her translations of Cavafy's poetry, as well as her recognition of Greek female poets, and included her in modern Greek studies courses, bibliographies, scholarship, and public literary and poetry events. In 2008 in an edition by Van Dyck of the poems of Katerina Anghelaki-Rooke, the translations of the poems of the latter by Dalven, Edmund Keeley, Jane Assimakopoulos, and Kimon Friar were included. ${ }^{27}$ Dalven was lauded as one of the notable translators of this passionate poet.

${ }^{25}$ Charles Simic, "Some Sort of a Solution: The Collected Poems by C. P. Cavafy, translated by Evangelos Sachperoglou," London Review of Books 30 (2008), 6:32-34.

${ }^{26}$ Karen Van Dyck, "Greek Poetry Elsewhere," Gramma 8 (2000), 81-98.

${ }^{27}$ Katerina Anghelaki-Rooke, The Scattered Papers of Penelope, ed. Karen Van Dyck (Manchester, 2008). 


\section{Rachel Dalven as a Playwright}

Dalven wrote seven plays. The first, entitled $A$ Season in Hell, was about the French poets Rimbaud and Verlaine and was produced at Off Broadway in $1950 .{ }^{28}$ She wrote a radio drama, Hercules, aired in Nashville in 1952, and its script was published the following year. ${ }^{29}$ The play Judas was an English version of the three-act play of Spyros Melas; the original was first shown in Athens in 1934 and Dalven had previously translated it. ${ }^{30}$ Her one-act play Toula was produced at Fisk University in 1953 and later developed into a full-length play retitled $A$ Matter of Survival, presented at the Twelfth Night Club, New York. In 1980 in New York, Dalven wrote the play Above All, Greek, and Esther, produced in New York in 1986. Her last play, finished in 1991, was entitled Our Kind of People; it was an autobiographical play about Greek Jewish immigrants in the United States. Before her death in 1992 it was performed at a synagogue in Manhattan, and shortly after, in the fall of 1992, it was staged at a Brooklyn theater, and at a Greek Orthodox cathedral in Manhattan.

\section{Rachel Dalven as a Historian of the Romaniote Community of loannina}

In 1992 Dalven wrote a biography of Anna Comnena, the noted female Byzantine historian and author. ${ }^{31}$ The work stemmed from Dalven's passion for the literature and culture of Greek Byzantine society.

In The Jews of Ioannina, ${ }^{32}$ Dalven presented a detailed history of the Jews of the town since the tenth century, showing their particular traditions, liturgy, culture, customs, folk beliefs, relations with the local Greek Orthodox community, their demise in the Holocaust, and the Judeo-Greek dialect (also known as Yevanic), which was more than phraseology but

${ }^{28}$ Bruce Lambert, "Rae Dalven, 87, Professor and a Historian of Jews in Greece," The New York Times (3 Aug. 1992), http://www.nytimes.com/1992/08/03/nyregion/rae-dalven87-former-professor-and-a-historian-of-jews-in-greece.html [retrieved: 28 Sept. 2017].

${ }^{29}$ Encore (Spring 1953), 23-36.

${ }^{30}$ Israel J. Katz, "Rachel Dalven: A Bibliography," Bulletin of Judeo-Greek Studies 11 (1992), 35-38.

${ }^{31}$ Rae Dalven, Anna Comnena (New York, 1972). Anna Comnena (1083-1148) was a historian and a princess of the Byzantine Empire. She was also a writer and a physicianshe ran the hospital her father built in Constantinople. Comnena wrote a fifteen-volume work on the reign of her father, the Byzantine Emperor Alexios I, entitled Alexiad.

${ }^{32}$ Dalven, The Jews of Ioannina. 
had a religious literary and spoken tradition dating back to Byzantium. ${ }^{33}$ The Romaniote Jews were named after Romania, the second Rome, or the eastern Mediterranean part of the Roman Empire, which became the Byzantine Empire. The Romaniotes were the original Jewish population of the territories of the Byzantine Empire, Constantinople, the Balkans, and Asia Minor, and they spoke Greek and Judeo-Greek. The Jews of Byzantium and afterward those of the Greek-speaking communities of the Ottoman Empire were coined Romaniotes. Dalven claimed that the term derived from the Venetian name for Greece, "Romania," which entered into Hebrew, ${ }^{34}$ but its origins were older than the Venetians, dating back to the late classical period and Byzantium. According to Sharf, in the seventh century Byzantine Jewry, like the Byzantine Empire, marked a continuation of the Roman period and numbered about 100,000 people in the areas left to Byzantium after the Arab conquests..$^{35}$ The term was used by Rabbi Natan Ben Yehiel mi-Romi (from Romania) in the eleventh century in his work the Aruch, a Talmudic dictionary dedicated to understanding foreign words in the Talmud in Greek, Persian, Aramaic, Latin, and other languages. ${ }^{36}$ Dalven noted how prayer was conducted in accordance to Mahzor Romania until the Spanish exiles arrived into the city area in the early sixteenth century and dominated the Romaniote communities of the Greek Peninsula, introducing Sephardic prayers and halakhic regulation.

${ }^{33}$ See Rachel Dalven, “Judeo-Greek,” Encyclopedia Judaica 10 (1971), 426-427.

${ }^{34}$ Dalven, The Jews of Ioannina, XI.

${ }^{35}$ Andrew Sharf, Jews and Other Minorities in Byzantium (Ramat Gan, 1995), 54.

${ }^{36}$ Abraham Tal, "The Historical Dictionary of the Hebrew Language: A Presentation," in Eberhard Bons et al. (eds.), Biblical Lexicology: Hebrew and Greek. Semantics - Exegesis - Translation (Berlin, 2015), 309-326. This predates Starr's premise that the term "Romaniote" was based on Romania, the reconstruction of the Byzantine Empire after the Fourth Crusade in 1203-1204. See Joshua Starr, Romania: The Jewries of the Levant after the Fourth Crusade (Paris, 1949), 9. "Rum" was the Turkish word for the Greek-speaking Greek-Orthodox persons of the Byzantine Empire. Cemal Kafadar points to a definition parallel to its rabbinic use in the eleventh century: "The word 'Rum' or diyar- $\iota$ Rum for defining a cultural as well as a physical space (the lands of Rome, limited over time to the eastern Roman lands, i.e. Byzantium) was adopted from earlier Arabo-Persian usage but now stretched by Turkish speakers to refer to the zone that they inhabited and in large part also governed. Turks and others who moved westward during and after the eleventh century adopted and reworked many geographical names in the eastern Roman lands on the basis of what had already been 'Islamized' and used by Arabs, Persians, or Kurds." See Cemal Kafadar, "A Rome of One's Own: Reflections on Cultural Geography and Identity in the Lands of Rum," in Sibel Bozdogan, Gulru Necipoglu (eds.), Muqarnas: An Annual on the Visual Culture of the Islamic World. History and Ideology: Architectural Heritage of the "Lands of Rum" (Leiden-Boston, 2007), 7-25. 
At this point Ottoman Turkish influences infiltrated into the Judeo-Greek dialect of the Romaniote Jews of the Greek Peninsula.

In her seminal book on the Jews of Ioannina, Dalven published the musical scores of many Jewish hymns from Ioannina, such as songs for Purim, the Sacrifice of Isaac, or Yarabi. ${ }^{37}$ Amongst the many diverse finds, community characteristics and achievements, and historical accounts, Dalven depicted the yearly cycle, burial customs, and unusual traditions like Purim Saragosa, the alef birth certificate/amulet placed over the bed until the circumcision, and the silver shaddai ${ }^{38}$ ornaments hung over the ark in the synagogue.

Ioannina was the largest Romaniote community in the world at the turn of the twentieth century (1890-1910), numbering some 7,000 Jews before most of its community members migrated to New York at the beginning of the century. Later most of the 1,700 or more ${ }^{39}$ Jews who remained were annihilated at Auschwitz-Birkenau at the hands of the Nazis.

Dalven revealed how most of the Jewish community were under the religious and communal authority of the elder Shabetai Cabilli, vicepresident of the Jewish community, who parlayed with the Nazi occupation commanders and believed that as long as Jews met the German demands for money and supplies, they would not be touched. He influenced parents to demand that their sons return from the partisan groups in the mountains. Yet in the end, not only was Cabilli duped, but the Jews were deported and annihilated. ${ }^{40}$ Dalven noted the resentment of the local Greek Orthodox nationalist revolutionaries in 1909 when six Jewish peddlers were murdered in the countryside and their ears were sent in an envelope to the Jewish community of Ioannina in response to the Jews not siding with the Greek national movement. However, in her analysis of the interwar period she did not analyze the continuing resentment toward Jews from the time of

37 Yarab, "God," was a hymn sung by the Romaniote Jews by the father in honor of the birth of his new born son, after the circumcision. Analyzed by Ióséph M. Matsas, Gianniótika Evraïka tragoudia (Ióannina, 1953), 45-47.

${ }^{38}$ Sadai or Shaddai was one of the ancient names for God. Dalven explained it was used in Ioannina "as a plea for God's protection." Dalven, The Jews of Ioannina, 109.

${ }^{39}$ See Aviva Ben-Ur, Sephardic Jews in America: A Diasporic History (New York-London, 2009), 105; and Judith Mizrahi, 703 Sephardim in America: Diversity within Cohesiveness (New York, 1993), 7.

${ }^{40}$ Rachel Dalven, "Holocaust in Janina," in Haham Dr. Solomon Gaon, Dr. M. Mitchell Serels (eds.), Del Fuego, Sephardim and the Holocaust (New York, 1995), 45-68. See also Yitzchak Kerem, “The Sephardim Resisted Too!” (Jerusalem, 2004), https://www. academia.edu/4595338/_The_Sephardim_Resisted_Too_Yad_Vashem_Jerusalem_2004 [retrieved: 28 Sept. 2017]. 
Greek sovereignty in 1912 until the deportation of the Jews to Auschwitz during the Holocaust. ${ }^{41}$

Leda Papastefanaki noted the stratification of the local Jewish community on the basis of economic class between the affluent, the merchant class, and the poorer peddlers, craftsmen, and unskilled laborers, and on the basis of gender, and the ensuing internal Jewish conflicts. In the 1920s, Jewish women began to take active roles in the work world, helping their husbands and relatives in their stores and workshops. She also noted the tensions between the newly educated and more secularized Alliance Israélite Universelle graduates in the free professions and the traditional religious community members and rabbis. She also noted the threats and violence in Ioannina against the Jews in 1934, incited by the local chapter of the ultra-nationalist Tria Epsilon youth movement, which had provoked the large-scale Campbell riots in Salonika that destroyed the eastern Campbell suburb of poor Jewish fisherman and port workers. ${ }^{42}$

Dalven, while secular and non-observant in her personal life, identified with the ethnicity and traditions of the Romaniote Jews. Her grandfather in Ioannina, though an affluent man, had many daughters to marry off and many dowries to finance, so he did not give the daughters gold chains, as he hoped that their husbands would eventually buy them for the wives. As a struggling immigrant, Dalven's mother could never boast or proudly wear such an expensive chain as a young single woman in Ioannina at the end of the nineteenth century (toward the end of the Ottoman period), and neither could she do this as an adult married woman living modestly in New York as an immigrant in the 1910s and 1920s, during the depression, or afterward. Dalven made research trips to Ioannina in the 1930s, but could never find such a chain to buy for her mother as a cherished gift. After the Holocaust, Ioannina jewelers had no such fancy and expensive chains. Only on a research trip to Istanbul in the early 1960s, undertaken as a part of Byzantine studies, could Rachel find and afford such a chain, which she purchased from a Jewish merchant at the Istanbul bazaar. Upon arriving home in New York, Rachel gave the chain to her aging widowed mother, who was hesitant to receive such an expensive gift, but wore it

${ }^{41}$ See Dalven, The Jews of Ioannina, 33; and Yitzchak Kerem, "The Jews of Ioanina Between Ottoman Loyalty and Greek Resurrection, 1900-1913," Ha-mizrah he-hadash 39 (1997-1998), 46-54.

${ }^{42}$ See Leda Papastefanaki, “'Anthropoi tapeinoí, frónimoi, noikokyreménoi kai kaloí oikogeneiárches...’: Pros mia koinoniké istoría tes Evraïkés Koinótetas ton Ioannínon ton 20 ó aióna,” in Mahera, Papastefanaki (eds.), Evraïkés koinótetes, 127-144. 
gloomily since she had passed her prime and would have enthusiastically cherished it as a young married woman had she received it from her husband at the stage of life when she would have flaunted it socially in front of friends and relatives. The story was published under the title "The Golden Chain" as a memoir from the homeland in an anthology of Sephardic American literature by Diane Matza, which appeared in 1997, several years after Dalven's death. ${ }^{43}$

Dalven wrote numerous articles on Romaniote Jewry as a group and on individual personalities in the Encyclopedia Judaica and The Blackwell Companion to Jewish Culture. For example, in both publications she wrote about the author, artist, and film director Nestoras Matsas, and in the Encyclopedia Judaica about the well-known Jewish Greek authors Julius Caimi of Corfu and Athens, Joseph Matsas of Ioannina, Baruch Schiby of Athens, and Joseph Sciaki of Chalkis and later Athens.

Together with the noted musicologist Israel Katz, Dalven published three traditional Judeo-Greek hymns and their tunes. ${ }^{44}$ In her The Jews of Ioannina she also published Romaniote liturgical poems as well as several pages on the Judeo-Greek language and its Epirus Ioanniote dialect.

\section{Rachel Dalven as a Non-Ashkenazi Jew and the Identity of Romaniote-Sephardic Hybridity}

Dalven was the president of the American Society of Sephardic Studies, and she edited The Sephardic Scholar under the auspices of the Sephardic Studies Program at Yeshiva University. As a Romaniote Jew she belonged to the New York City Jewish women's group The Daughters of Ioannina and served at one time as its president. She was also a board member of the American Friends of the Jewish Museum of Greece in Athens.

While Dalven was a part of the Greek-speaking Ioanniote Jewish enclave in New York, she was also Sephardic. By the early 1970s, "Sephardic0" became a generic term grouping all those not Ashkenazi: among them, Bukharans, Egyptians, Judeo-Spanish speaking Turks and Salonikans, Iraqis, Moroccans, early colonial Portuguese Jews and their descendants,

${ }^{43}$ Rae Dalven, "The Golden Chain," in Diane Matza (ed.), Sephardic American Voices: Two Hundred Years of a Literary Legacy (Hanover-London, 1997), 80-86.

${ }^{44}$ Rachel Dalven, Israel J. Katz, "Three Traditional Judeo-Greek Hymns and Their Tunes," The Sephardic Scholar 4 (1979-1982), 84-101. 
Syrian Jews, and even Georgian Jews. They all included in the American Sephardic Federation.

Joseph Papo described the Greek-speaking Romaniote Jews in New York City as "the Greek Sephardim who maintained their individualism even within the framework of their own group." 45 On the Lower East Side of Manhattan, the Ioanniote Jews had three exclusive Ioanniote synagogues/prayer groups: Hevrat ahavah ve-ahvah (Love and Brotherhood Society of Janina) on Allen Street was founded in 1907; Knesset Israel (The Israelite Community of Janina), which broke away in 1913; and finally in 1926, ${ }^{46}$ the two merged into Agudath Ahim Janina (United Brotherhood of Janina) and acquired a building on 28 Broome Street, which exists today and houses a Romaniote Museum on its second floor. As Ioanniote Jews prospered economically, they moved to Bensonhurst, Brooklyn, where they founded the Kehillah Sepharadith, which in 1963 became the Sephardic Center of Mapleton. In Harlem, the Ioanniote Jews were dominant amongst the Sephardic minority in the neighborhood. In 1907 they founded the Tikvah Tovah (Good Hope Society). The Ioanniotes were a majority there with Sephardim from Smyrna, Salonika, the Dardanelles, and Castoria. Their synagogue, Shearith Israel Mitourkia (Remnants of Israel from Turkey), opened in 1911 and in 1958 it relocated to the Bronx and changed its name to Shearith Israel of Janina. ${ }^{47}$

Historically, in Ioannina, due to the major influx of Sephardim in the region after the 1492 Spanish expulsion, the Mahzor Romania prayer book fell by the wayside, and Romaniote Jews adopted Sephardic prayer and halakha religious law. The Ioanniote Romaniote Jews, however, preserved numerous Romaniote traditions, customs, religious poems, and ritual art. Shmuel Refael depicted Dalven's contribution to onomastic research on Greek names, and her depictions of Greek Jewish as well as Ladino (Judeo-Spanish) nicknaming professions and characteristics:

Dalven's research brings together a number of important topics in onomastic research on Greek Jews. She documents the continuing tendencies to nickname people after their physical characteristics, their personality traits, and their vocations. She also uses Ladino nicknaming as a gendered process, comparing names given to male and female children and examining attendant rationale or impulse. Dalven

${ }^{45}$ Joseph M. Papo, Sephardim in Twentieth Century America: In Search of Unity (San Jose-Berkeley, 1987), 26.

${ }^{46}$ Ibid., 311.

47 Ibid., 312. 
notes the widespread use of nicknames in the Greek region of Epirus, and that the substitution of nicknames for officially given names varied.

In her descriptions of nicknames derived from professions she explains how Konduratzis, "cobbler," went by this epithet because of his shoemaking. Sakis (Turkish for "one who limps") was conferred on a lame person. Some of the most amusing nicknames were those bestowed in recognition or blunt announcement of personal characteristics or legendary behavior. Kaokas was the baker who burned the fare he had prepared for a festival. The nickname has its origins in the word Kaio, which means burning or incineration in Greek. Even though Dalven's work is not accompanied by a range of etymological or linguistic data, its distinction lies in the multiplicity of stories about lifestyles and folkways which it brings to the fore. All of these have been, and continue to be, vital and indispensable in the creation of human nicknames overall, and Sephardic Ladino epithets in particular. ${ }^{48}$

In 1967 the American Society of Sephardic Studies (ASOSS) was founded with the support of Yeshiva University. Dalven edited its journal The Sephardic Scholar, funded by the University, which appeared only four times from 1979 to 1982. There has never been another English-language printed journal for Sephardic studies in North America. The ASOSS held meetings on campus and opened its membership to non-Jewish scholars in the United States and Canada. However, the arrangement of relying on others caused discontent, and became a significant issue which eventually led to the Sephardic, Romaniote, and Eastern Jewish communities mass assimilation, deterioration, and inability to train dynamic rabbis, educators, lay leaders, and scholars, along with their inability to stand on their own and thrive. Rachel Dalven's brother Joseph Dalven, director of the Sephardic Old Home in Brooklyn, explained this dilemma and the root of future tragedy:

The more non-Sephardic (Yeshiva) aid, the more atrophy of the drive and incentive necessary for healthy organic development will be the consequence. A certain amount of infusion may be necessary at this juncture of our development but, in the final analysis, it must have the native relevant ingredients for normal organic growth . . . the more dependent you allow yourselves to become, because it is easier, the more you atrophy and the more dependent you become. ${ }^{49}$

After her death, Steven Bowman, a historian of Byzantine Jewry and Greek Jewry in the Holocaust, wrote the following about Dalven:

${ }^{48}$ Shmuel Refael, "Voices from the Past: Judeo-Spanish (Ladino) Nicknames among the Israeli-Sephardic Jews from Salonika," in Stacy N. Beckwith (ed.), Charting Memory: Recalling Medieval Spain (New York, 2000), 144-170.

${ }^{49}$ Papo, Sephardim in Twentieth Century America, 210. 
Rae was a tough independent lady who chose a life of intellectual stimulation rather than the traditional home life of her contemporaries. She dedicated her life to scholarship in general and to the fate of her people in particular. She was active in getting material published, in organizing cultural events, in her service to the Ioanniote, Greek, and Sephardi communities. She was a frequent participant in activities at the Onassis Centre and contributed many books to its collection. ${ }^{50}$

She married a Romaniote Ioanniote Jew Jack Negrin for a short time, but had no children. Her brother Joseph, quoted above, also was a researcher of sexuality and published numerous works on the subject. In 1973, Rachel Dalven received the Gold Key Award of the Columbia Scholastic Press Association of the Graduate School of Journalism of Columbia University. ${ }^{51}$

\section{Conclusion}

Rae (Rachel) Dalven was in the right place at the right time. In New York City, she had contact with prominent publishers, literary critics, authors, and affluent supporters of the arts. As an academic she received many grants that enabled her to travel numerous times to Greece, Turkey, and other European countries. Her royalties from poetry publications also assisted in her research and translations. Her exposure in the Greek American press helped her reach recognition and spread appreciation for modern Greek poetry in translation.

Dalven benefited from an early exposure to Greek poetry. This enabled her to become one of the first translators of Greek and propagators of leading modern Greek poets. She was a pioneer who brought to light female Greek poets under Greek democracy after the end of the Greek Junta (coup d'état) from 1974 onward. Likewise, she was the first researcher to take both a macro and a micro view of Ioanniote Romaniote Jewry in its entirety. She benefited from first-hand familiarity with Ioanniote Jewry during the 1930s, before the German occupation and their demise in Auschwitz-Birkenau in 1944.

Dalven was a very educated Romaniote Jewish woman, and she wrote about and included Romaniote Jewish women in her research and publications on social history. She noted their traditions, folk beliefs, cuisine,

${ }^{50}$ Steven Bowman, "Rachel Dalven: An Appreciation," Bulletin of Judeo-Greek Studies 11 (1992), 34.

51 Yitzchak Kerem, “Dalven, Rachel,” Encyclopedia Judaica 5 (2007), 184. 
and life cycle, from birth to marriage to death. Her anecdotes and impressions were some of the last records of the community written before their annihilation in the Holocaust as well as depictions of the first generation of Ioanniote Jewish immigrants to the United States-a generation no longer to be found and heard.

Dalven was not a historian, linguist, or scholar of Jewish thought, but through her dedication to her Jewish Greek Romaniote heritage, identity, and religious group, she mastered facets of all these disciplines in her research and publications. In a similar fashion, she became a translator of modern Greek to spread awareness of Jewish and modern Greek poetry and its first-rate literary figures. Beyond a doubt, it was her efforts which brought Eliya, Cavafy, and Ritsos to a general audience in the original and in English translation.

Yitzchak Kerem

The Hebrew University of Jerusalem ykeremster@gmail.com 